APPLIANCES

STANDARDIZED TONOMETERS IN GREAT BRITAIN"

BY

\author{
C. R. S. JACKSON $\dagger$
}

Edinburgh

THE purpose of this paper is to set out the steps which led to the first attempt to establish the standardization of tonometers in Great Britain, and to describe the method by which it is proposed that such standardization shall be achieved.

Acknowledgment must here be made to those upon whose detailed preliminary work the present project is freely based, and many of whose techniques and ideas are incorporated herein. Of first importance in this connection is the American Academy of Ophthalmology and Otolaryngology, whose Committee on Standardization of Tonometers has gone far to arrive at a solution of many of the problems involved. Dr. Jonas S. Friedenwald has placed the knowledge of this committee, of which he was chairman until succeeded by Dr. Kronfeld, at my disposal, and has, by his encouragement and ready help, done much to enable us to take a step towards the international standardization of tonometers.

\title{
Development of the Problem
}

Schiötz, who originally described his instrument in 1905, showed his appreciation of the desirability of accurate manufacturing standards by establishing a factory in Oslo. These tonometers carried a certificate to the effect that they were replicas, in construction and performance, of the reference standard instrument. In a long series of calibration tests, carried out on excised cannulated eyes, Schiötz produced conversion curves which enabled scale readings to be converted into millimetres of mercury $(\mathrm{mm}$. $\mathrm{Hg})$ of intraocular pressure.

While, therefore, the only Schiötz tonometers on the market were those coming from this one workshop, the question of standardization did not arise, but this state of affairs did not last very long, for the manufacture of "Schiötz-type" tonometers spread to other countries and the instruments" produced often resembled the original in little but appearance. In spite of this, these later tonometers were still sent out with reproductions of the original Schiötz calibration curves. Many workers have examined in detail the construction of such tonometers, and the experience of Harrington and Parsons (1941) is typical:

${ }^{*}$ Received for publication July 24, 1953.

tIn receipt of a grant from, and working under the auspices of, the W. H. Ross Foundation (Scotland) for the Study of the Prevention of Blindness. 
We have carefully checked the weights and measurements of a large number of "Schiötz" tonometers, some manufactured in Europe and some in the United States. We found no instrument that adhered to Schiötz' original specifications and no two instruments that were alike in more than the diameter of the plunger.

No blame can be justly attached to the manufacturers in this matter, for the profession had given them no guidance as regards acceptable specifications, or the effects of apparently trivial deviations from standard.

\section{NEED FOR STANDARDiZaTION}

When one is interested in the problem of tonometry, the question is often asked whether standardization of instruments is worth-while, or even desirable. Those who regard such refinements as unnecessary argue that we are dealing here with a clinical instrument, and not with one of scientific accuracy, and with an examination in which many factors affect the readings. The values obtained depend not only upon the skill of the observer, but also upon the position of the patient, the length of time for which the instrument rests on the eye, and a number of other variables. These " reading errors" have been assessed by Friedenwald (1950) as of the order of $\pm 3 \mathrm{~mm}$. $\mathrm{Hg}$, and the "instrumental errors" of standardized tonometers as of the order of $\pm 2 \mathrm{~mm}$. $\mathrm{Hg}$.

While it is true that the tonometer is of limited value when used on an eye on an isolated occasion, it remains a valuable instrument in the study of the progress of disease in a given case, and particularly in the assessment of the results of treatment in glaucoma. Standardization of instruments will do two things. It will remove the present necessity for each surgeon to get to know what he may expect from his own instrument; and it will ensure that readings obtained from the same patient with different instruments are comparable, at least within the limits of error referred to above.

Since Mackenzie (about 1830) first realized the essential importance of raised intra-ocular pressure in the pathogenesis of glaucoma, about fifty different types and modifications of tonometers, of varying degrees of complexity, have been described. Many of these are described and illustrated by Lloyd (1930), and the more recent literature contains descriptions of new instruments, among them the aplanation tonometer of Maurice (1951) and various electronic models.

The question whether the Schiötz tonometer is about to be superseded cannot be answered dogmatically, but I think it unlikely. Here we have an instrument which has been in demand for over 30 years, which is easily portable and adequately rigid to stand the handling of daily use, and sufficiently accurate for clinical purposes.

\section{Checking Stations Elsewhere}

Schiötz, realizing the fundamental need for standardization, set up his own workshop to produce the instrument, and also issued certificates with the instruments when they were sold. 
When the manufacture of tonometers spread to other centres, certification was, in general, neglected. An early exception to this neglect is seen in some of the German instruments which, certainly in the 1930s, were issued with certificates stating how their construction compared with that of the original Schiötz instruments.

In the course of time, various appeals for international standardization have been made, among them that of Comberg (1930) at the XIII International Congress, when a Committee was set up to study the problem. Individual effort was largely ineffective, although tonometer checking stations had been set up in various centres (e.g. in 1923 by Arnold at Tübingen, in 1925 by Schiötz at Oslo, and in 1928 by Comberg at Berlin).

It was in the United States, however, that the first move was made toward the now accomplished goal of standardization of tonometers on a national scale. In the 1930s Schoenberg and Posner set up a testing laboratory to examine the physical characteristics of the tonometers then in use. This venture was sponsored by the National Society for the Prevention of Blindness and a report was published by Schoenberg and Posner (1944). The desirability of attacking the problem on a national scale was recognized and, in 1942, the American Academy of Ophthalmology and Otolaryngology established a Committee on the Standardization of Tonometers, under the Chairmanship of Dr. Friedenwald. This has led to the establishment of three checking stations (in New York under Dr. A. Posner, in Chicago under Dr. Peter Kronfeld, and in San Francisco under Dr. D. O. Harrington and Dr. R. Shaffer.)

The general method of examination of a tonometer has been described by Posner (1943), and it is not proposed to enter into the details of the technique here. Suffice it to say that, by means of various balances and gauges, some of which have been specially designed for this work, all the relevant features of a tonometer's construction and performance are tested, and a comparison is made between these and the specification of the standard instrument. The work is under the strict control of the Committee on Standardization of Tonometers, but the routine testing of new instruments is now undertaken by an independent commercial organization, Electrical Testing Laboratories, Inc., of New York, by whom a charge is made to the manufacturer for testing his product. Certified tonometers have now been on sale in the United States for about 6 years.

\section{What Standards aRe to BE Adopted?}

In a series of calibration experiments lasting more than 20 years, Schiötz drew up his chart, by which tonometer scale readings were to be converted into millimetres of mercury showing intra-ocular pressure. It is doubtful if the readings thus obtained represent the actual intra-ocular pressure, for they are dependent upon other factors, including the rigidity of the coats of the eye and their resistance to deformation. I agree with Duke-Elder (1937) 
that it is desirable to refer to the results obtained as " $\mathrm{mm}$. $\mathrm{Hg}$ (Schiötz)", as an indication of the doubt that these are true millimetres of mercury. With these qualifications, however, it is likely that the results of Schiötz are a close approximation to the truth. In his masterly theoretical analysis of the problem of tonometry, with particular reference to the effect of differing ocular rigidity upon the results obtained, Friedenwald (1937) has modified slightly the original Schiötz curves, and the Committee on Standardization of Tonometers has accepted these as a basis for the curves issued with certified tonometers. I understand, however, that a more accurate set of curves is likely to result from calibration studies now proceeding, and that the present curves must be regarded as temporary, pending a final decision.

Taking the original standard Schiötz instrument as a basis, our American colleagues have drawn up detailed specifications for new instruments, and have laid down degrees of tolerance within which deviations from the standard will be accepted. The development of these specifications has been gradual, extending from Specification No. 1 (1944) to Specification No. 4 (March, 1952). A copy of this latest specification appears as an Appendix to this paper.

These specifications have been drawn up in agreement with the manufacturers, and the tolerances are such as can be met by current modern workshop practice. To insist on too high a standard of tolerance would have a serious effect on the retail price of the finished article.

\section{The Present Venture}

It is proposed, in due course, to make available standardized tonometers for purchase in Great Britain. This will be achieved in conjunction with the manufacturers, by introducing the same standards and specifications as are current in the United States. The chief manufacturers have already agreed to co-operate, and they appreciate the opportunity of improving the usefulness of their instruments. Provisional estimates indicate that this change will lead to a rise in the price of tonometers, but this increase is not likely to be great. A tonometer checking station will be established in Edinburgh with the support of the W. H. Ross Foundation, and new instruments will be issued with a certificate of compliance with the currently accepted standards. Certain technical difficulties have yet to be overcome, and the profession will be notified when certified tonometers are available. It is to be hoped that this attempt to remove at least some of the sources of inaccuracy from instrumental tonometry will meet with the approval and support of ophthalmologists.

\section{POSITION WITH REGARD TO OTHER INSTRUMENTS}

All calibration studies so far undertaken have been concerned with the original Schiötz instrument (with weights) and with the Schiötz-Gradle 
tonometer, and it is with the Schiötz instrument alone that this present work is concerned.

With regard to "Schiötz-type" instruments which are already in service, and whose owners may wish to know whether re-calibration is possible, no definite programme has been agreed upon. American workers, as a result of experience gained in the examination of hundreds of tonometers, have arrived at a series of mathematical correction factors which are applicable to such instruments, and it may be possible to introduce a system of recalibration in Great Britain. This aspect of the problem is still being studied.

\section{REFERENCES}

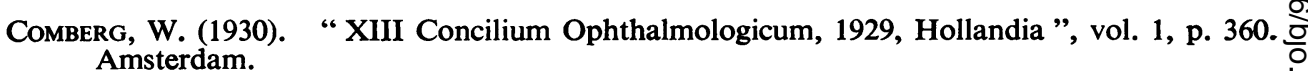

Duke-ElDER, S. (1938). “ Text-book of Ophthalmology”, vol. 2, p. 1192. Kimpton, London.

FriedenwaLD, J. S. (1937). Amer. J. Ophthal., 20, 985. (1950). Ibid., 33, 1523.

Harrington, D. O., and Parsons, A. H. (1941). Arch. Ophthal. Chicago, 26, 859.

LLOYD, R. I. (1930). Amer. J. Ophthal., 13, 396 and 496.

MAURICE, D. M. (1951). British Journal of Ophthalmology, 35, 178.

Posner, A. (1943). Arch. Ophthal. Chicago, 30, 1.

SCHOENBerg, M. J., and Posner, A. (1944). Amer. J. Ophthal., 27, 368.

SCHIÖTZ. (1905). Arch. Augenheilk., 52, 401. 


\section{APPENDIX}

\section{Specification No. 4 for Schiötz Tonometers (March, 1952) \\ All tonometers and plungers to carry serial numbers.} The manufacturer's name to be designated on the tonometer.

\begin{tabular}{|c|c|c|c|}
\hline \multirow{2}{*}{ No. } & \multirow{2}{*}{ Test } & \multicolumn{2}{|c|}{ Specification } \\
\hline & & Standard & Limits \\
\hline \multirow[t]{7}{*}{1} & $\begin{array}{l}\text { Weight } \\
\text { Plunger, lever and pointer }\end{array}$ & (grammes) & \\
\hline & Scale indication 5 & 5.5 & $\pm 0 \cdot 15$ \\
\hline & Scale indication 10 & 5.5 & \pm 0.25 \\
\hline & Tonometer without handle & $16 \cdot 5$ & $=0.5$ \\
\hline & Load $7 \cdot 5$ & $2 \cdot 0$ & \pm 0.02 \\
\hline & Load 10.0 & $4 \cdot 5$ & $=0.02$ \\
\hline & Lodo 10.0 & & $=0.02$ \\
\hline 2 & $\begin{array}{l}\text { Friction between plunger and sleeve } \\
\text { The test for friction between the plunger and sleeve shall be that the plunger slides } \\
\text { freely in the barrel when its axis is no more than } 25^{\circ} \text { from the horizontal. This } \\
\text { test to be made with the tonometer face up, face down, and in the two lateral } \\
\text { positions }\end{array}$ & \multicolumn{2}{|c|}{ Negligible } \\
\hline 3 & Friction between handle and sleeve & \multicolumn{2}{|c|}{ Negligible } \\
\hline 4 & $\begin{array}{l}\text { Foot-plate } \\
\text { Diameter } \\
\text { Curvature } \\
\text { Diameter of curved surface } \\
\text { Tonometer foot-plate to be free from visible dents, tool marks, and scratches, } \\
\text { and to have a highly polished surface. The criterion regarding the polish } \\
\text { will be whether or not foot-plate curvature can be satisfactorily measured by an } \\
\text { optical method. }\end{array}$ & $\begin{array}{l}10.1 \mathrm{~mm} \text {. } \\
15.0 \mathrm{~mm} . \\
9.0 \mathrm{~min} .\end{array}$ & $\begin{array}{l} \pm 0 \cdot 2 \\
\pm 0 \cdot 25\end{array}$ \\
\hline 5 & $\begin{array}{l}\text { Plunger } \\
\text { Diameter (measured } 0^{\circ}-90^{\circ} \text { ) } \\
\text { Curvature } \\
\text { Edge curvature-smooth, radius } \\
\text { Plunger foot to be free from visible dents, tool marks, and scratches, and highly } \\
\text { polished }\end{array}$ & $\begin{array}{l}3.0 \mathrm{~mm} . \\
15.0 \mathrm{~mm} . \\
0.212 \mathrm{~min} \text {. }\end{array}$ & $\begin{array}{c} \pm 0.03 \\
\div 0.75 \\
0.300 \max \end{array}$ \\
\hline 6 & $\begin{array}{l}\text { Scale indication } \\
\text { On } 15 \mathrm{~mm} \text {. standard } \\
\text { On } 16 \mathrm{~mm} \text {. standard } \\
\text { On own block } \\
\end{array}$ & $\begin{array}{l}\text { (Tonometer } \\
\text { Scale) } \\
-1 \\
0 \\
0 \\
\end{array}$ & $\begin{array}{l}=0 \cdot 2 \\
\pm 0 \cdot 2 \\
\pm 0 \cdot 2\end{array}$ \\
\hline 7 & $\begin{array}{l}\text { Micrometer } \\
\text { Scale } 5 \\
\text { Scale } 10 \\
\text { Scale } 18 \\
\end{array}$ & $\begin{array}{r}5 \cdot 0 \\
10 \cdot 0 \\
18\end{array}$ & $\begin{array}{l} \pm 0.25 \\
\pm 0 \cdot 25 \\
\pm 1 \cdot 0\end{array}$ \\
\hline 8 & $\begin{array}{l}\text { Wobble } \\
\text { Plunger } \\
\text { Fulcrum } \\
\text { Pin at fulcrum to fit into its hole without wobble. Measurement of this } \\
\text { to be determined by inspection and by the smoothness and reproducibility of } \\
\text { the pointer reading on the micrometer block as the plunger is raised and lowered }\end{array}$ & $\begin{array}{l}0 \mathrm{~mm} . \\
0 \mathrm{~mm} .\end{array}$ & $\begin{array}{l}0.4 \max . \\
0.4 \max .\end{array}$ \\
\hline 9 & Extension of plunger below foot-plate $(\mathrm{mm}$.) & & 3.0 max. \\
\hline 10 & $\begin{array}{l}\text { Pointer } \\
\text { Depth (mm.) } \\
\text { Thickness }(\mathrm{mm} .) \\
\text { Distance between scale and pointer (mm.) }\end{array}$ & & $\begin{array}{l}3.0 \max . \\
0.25 \max . \\
1.0 \max \text {. }\end{array}$ \\
\hline 11 & Plunger contact with hammer & alar 5-10 scale & \\
\hline 12 & Hammer, underside smooth, free from pits & & \\
\hline 13 & Tonometer to have generally good construction & & \\
\hline 14 & $\begin{array}{l}\text { Test block to have a polished surface, } 16 \mathrm{~mm} . \pm .04 \text { spherical curvature } \pm \\
\text { sphericity over an area of } 11 \mathrm{~mm} \text {. minimum diameter }\end{array}$ & $\cdot 14 \mathrm{~mm} \cdot \mathrm{d}$ & eviation from \\
\hline 15 & $\begin{array}{l}\text { Tonometer case to be dust-free and to contain a place for the plunger and } 5.5 \mathrm{~g} \text {. } \\
\text { ment can be taken apart for packaging }\end{array}$ & weight so th & at the instru- \\
\hline 16 & Schiötz Chart correct & & \\
\hline
\end{tabular}

